\title{
FACTORS AFFECTING LABOR PRODUCTIVITY: EVIDENCE IN LISTED COMPANIES IN VIETNAM
}

\author{
Le Thanh Tung, Lam Thanh Hieu, Hoang Thi Trang
}

\begin{abstract}
This study aims to analysis the impact of some factors on labor productivity with the sample of 244 companies which listed on the Vietnam Stock Exchange in 2011-2013. Labor productivity determined in two ways: (i) the divide of revenue and the number of labor, (ii) the divide of profit after tax and the number of labor. Results showed that wage and company age have a positive relationship (helpful impact) to increase the labor productivity. The results also indicated that the number of employees has a negative relationship (harmful impact) to decrease the labor productivity of the companies during the period.
\end{abstract}

Keywords: labor productivity, wage, company age, employees, stock market, in Vietnam.

JEL Classification: D20, D24

\section{INTRODUCTION}

According to the report from Vietnam General Statistics Office (GSO) the labor productivity of Vietnam had continuously increased $6.4 \%$ in 2015 and the average growth of labor productivity was approximately $4.34 \%$ per year in the period of 2011-2015. Meanwhile, the statistics were published by the International Labour Organization (ILO) in 2015 showed that the labor productivity of Vietnam is still lower than other countries in the Association of Southeast Asian Nations (ASEAN). Specifically, Vietnam's labor productivity is only by $2 / 5$ compared with Thailand, 1/5 Malaysia or even 1/15 to Singapore. The International Labour Organization (ILO) forecasts that Vietnam's labor productivity will be able to catch up with the Philippines in 2038 and Thailand in 2069.

Vietnam has a golden age in labor force with the young structure of the population. In the year of 2015, Vietnamese labor force aged 15 and above was 54.61 million persons (Vietnamese population approximately among 90.7 million), up 185 thousand persons compared to 2014's similar period; labor force within working age was 48.19 million persons, rose 506.1 thousand persons. Laborers aged 15 and above working in all economic activities in 2015 reached an estimate of 52.9 million persons, rose 142 thousand persons from 2014, of which the sector of agriculture, forestry and fishery accounted for $44.3 \%$; the sector of industry and construction represented $22.9 \%$; the sector of services took $32.8 \%$. The rate of trained labor within working age in 2015 was estimated to reach $21.9 \%$, higher than the previous year's rate of $19.6 \%$. Because of the young population structure, the labor productivity must be speeded up to make more and more working place for young workers who continuously join the labor force (GSO, 2016).

The director of ILO Vietnam, Sziraczki (2015) explained the role of labor productivity on development including four reasons: (i) First, labor productivity drivers economic growth, a highly productive economy means it produces more goods or services with the same amount of resource; (ii) Second, labour productivity affects everyone, the businesses brings higher profit, the workers can reach to higher wages and better working conditions, the government increases tax revenues; (iii) Third, the current state of labour productivity is important to catch up with 


\section{Proceedings of the 8th International Scientific Conference \\ Finance and Performance of Firms in Science, Education and Practice}

many high-level countries (iv) Fourth, ageing population and economic integration also need to be taken into consideration.

However, labor productivity is really one of the weaknesses reduced the competitiveness of Vietnamese companies. Therefore, the research focus on the fact of labor productivity and the solutions to improve labor productivity is urgent topics to enhance the competitiveness of Vietnam's economy in the progress of international integration. Some theories of macroeconomics have confirmed increased labor productivity will increase not only the size of the gross domestic product (GDP) but also national income, thereby allowing increased savings and investment in order promote economic growth. Besides, the national labor productivity is determined by the productivity of companies in the country.

There are some economist's opinions which focus on the solutions taken to increase labor productivity and improving competitiveness in Vietnam. The Government needs to boost labor productivity to maintain its rapid economic growth. Some recent reports suggested a conclusion that the Vietnamese enterprises must be improved their labor productivity. Although labor productivity has increased in Vietnam, the growth is still lower than its potential. Therefore, labor productivity is a research topic is very urgent in Vietnam's economy at this time. However, the quantitative research in this field in Vietnam is quite low. This paper uses three methods simultaneously with panel data estimation including the Pooled, FEM (Fixed Effects Model) and REM (Random Effects Model) to analysis the relationship between some factors and labor productivity in Vietnam through the dataset from a sample of 244 listed companies on the Ho Chi Minh City and Hanoi stock exchange in the period of 2011-2013.

The structure of the paper includes 5 sections. Besides the introduction, section 2 presents an overview of the theoretical analysis and section 3 shows the research model and the dataset. The next one focus on the results and discussion. Conclusion and some governance implications presented in the last section of the article.

\section{LITERATURE REVIEW}

Labor productivity has a very important role supporting the economics growth. So it is one of the main topics about driver the development of countries. However, there are some different views about the labor productivity concept. The first concept of productivity was mentioned around 1766 in the Quesnay's study. In the early of the 20th century, there were some definitions of productivity as the relationship between the outputs and the inputs used to produce them. By 1950, the Organization for European Economic Co-operation (OEEC) gave a formal definition of productivity "Productivity is the quotient obtained by dividing the output by one of the factors in production progress" (Jarkas , 2010). So the simplest way to define productivity as the ratio of the outputs of an activity to the inputs consumed to make those outputs. More specifically, Isinika (1995) definition of productivity is the ratio of output (goods and services produced) per unit of input (labor, capital, materials). In other words, the "yield" shows the relationship between output and input.

The International Labour Organization (ILO) defines productivity as the ratio between "output of work" and "input of resources" used in the progress of creating wealth. This definition applies to an enterprise, an industry or an economy as a whole. In different industries, the output and input are also different. Productivity is simply the ratio between the amount product and amount of resources used in the course of production. The resources can be (unit of resource is in parentheses) land, material, plant and machinery, people and capital (Singh, 2014)

However, many administrators often misunderstand between productivity and labor productivity. In fact, productivity is more overall than labor productivity. According to some studies, the productivity is calculated not only divide output by the input but also add the efficiency or performance (Han \& Leong, 1996). Drewin (1982) defined labor productivity as 


\section{Proceedings of the 8th International Scientific Conference \\ Finance and Performance of Firms in Science, Education and Practice}

"amount of goods and services produced by a production factor (labor) in a unit time". Borcherding \& Liou (1986) implied that the labor productivity is the relationship between the number of products manufactured and labor costs. Kapp \& Sanchez (2012) suggested that the labor productivity is the added value of enterprises compared to the total of employees (fulltime workers).

Labor productivity depends on the ratio of inputs and output quantity obtained from productive labor process. Inputs are the resources used to produce goods and services, inputs are often used including a number of labor hours, a number of employees, wages. Outputs are goods produced or services provided, often including the number of goods and services, value-added sales, revenue, profit after tax. Some researchers suggested that labor productivity calculated by divided the amount of output by the number of employees (Wimmer, 2000; Mankiw, 2010). Siebert et al (2006) showed that the labor productivity can be calculated as revenue per labor hour (Riley \& Bondibene (2013) also made a similar calculation). Basker (2011) measured the labor productivity as the ratio of the revenue to a number of employees.

Considering the overall perspective, the national labor productivity depends on the productivity of country's industries, namely labor productivity of the business community, labor productivity of provinces or national. However the question "What enhance the labor productivity?" is very difficult to clearly answer. This is always a difficult issue since labor productivity affected by different factors. There were some empirical researches which had done on labor productivity in several countries, the developed or the developing group. Ingene's study (1982) showed that the labor productivity was affected by a number of specific factors to such style or scale of investment, the acreage of the store. The research of Thurik \& Kleiweg (1986) pointed out some specific factors of the companies as the acreage of shops, store formats or locations that affect labor productivity of enterprises. Findings of Rama (2001) demonstrated increasing productivity helped companies offset "wage shock" when the cost increase, thereby not occur layoff or decrease profit from increased wage offers. Specifically, it points to the incentive for managers to pay their employees more than the market-clearing wage in order to increase their productivity or efficiency, or reduce costs associated with turnover, in industries where the costs of replacing labor are high. This increased labor productivity and/or decreased costs pay for the higher wages.

Park (2008) showed that labor productivity of enterprises depends not only on wages but also the amount of employees, competitions, union organizations. Mayneris et al (2014) indicated that labor productivity depends on wages, a number of employees and the age of the company. Lee and Yuen (2015) studied the labor productivity in a sample of small and medium-sized enterprises (SMEs) in Malaysia, showed that wages and labor scale, the technological level has an impact on labor productivity.

\section{THE RESEARCH MODEL AND DATA}

Based on the theoretical frameworks about labor productivity as well as some empirical studies focus on the factors affecting labor productivity, our paper assumes three main factors affecting labor productivity in Vietnam including (i) wage level, (ii) the number of employees, and (iii) the age of the company.

The research model is presented in the following equation:

$$
\mathrm{LP}=\beta_{0}+\beta_{1} \mathrm{LW}_{\mathrm{it}}+\beta_{2} \mathrm{LE}_{\mathrm{it}}+\beta_{3} \mathrm{~A}_{\mathrm{it}}
$$

Which: $\mathrm{LP}_{\text {it }}$ (Ln Labor productivity) is the natural logarithm base of labor productivity; There are two equation kinds that use in this paper to calculated the labor productivity. First, labor productivity is the revenue divided by the number of employees (denoted LP1) and second, labor productivity is defined as profits after tax divided by the number of employees (denoted LP2). LW it (Ln company's wage) is the natural logarithm base of wage costs in the companies; 
$\mathrm{LE}_{\text {it }}$ (Ln company's employees) is the natural logarithm basing on the amount of employees in companies; $\mathrm{A}_{\mathrm{it}}$ (Company age) is the age of the companies (age-level is the number of years operated since it was established).

The database used for the study is the quarterly data with time-series style. This data was collected from the accounting balance sheets and annual financial reports of a sample including 244 companies listed on the stock market in Vietnam period 2011- 2013. As such, total sample had 730 quarterly observers. The descriptive statistics of research sample is presented in the table below:

Tab. 1 - The descriptive statistics of the collected data. Source: Calculated from the research data

\begin{tabular}{|l|l|l|l|l|l|}
\hline \multirow{2}{*}{ Description } & \multicolumn{5}{l}{ Variable } \\
\cline { 2 - 6 } & LE & LW & A & LP(1) & LP(2) \\
\hline Mean & 6,168 & 16,277 & 9,957 & 20,722 & 17,766 \\
\hline Median & 6,095 & 16,425 & 7,000 & 20,655 & 17,830 \\
\hline Maximum & 10,81 & 20,050 & 56,000 & 24,190 & 22,300 \\
\hline Minimum & 3,000 & 10,330 & 1,000 & 18,160 & 10,100 \\
\hline Observers & 730 & 730 & 730 & 730 & 730 \\
\hline
\end{tabular}

\section{FINDINGS}

Research methods using panel data regression (panel data) are applied simultaneously evaluates both three ways including the Pooled data model (PM), the Fixed effects model (FEM) and the Random effect model (REM). In which labor productivity was calculated based on two calculations of data are the total revenue and the total profit after tax of companies.

Tab. 2 - Results using data regression variables LP1. Source: Calculated from the research data

\begin{tabular}{|l|l|l|l|}
\hline Dependent variable: LP1 & FEM & REM \\
\hline Variable & PM & $-100,06^{* * *}$ & $-101,196^{* * *}$ \\
\hline C & $-75,6789^{* * *}$ & $(-4,6796)$ & $(-4,7412)$ \\
\hline LW & $(-13,8189)$ & $0,0764^{* * *}$ & $0,1252^{* * *}$ \\
& $0,2957^{* * *}$ & $(4,0066)$ & $(7,0285)$ \\
\hline LE & $(147,8744)$ & $-0,7292^{* * *}$ & $-0,4993^{* * *}$ \\
& $-0,2328^{* * *}$ & $(-16,936)$ & $(-15,7487)$ \\
\hline $\mathrm{A}$ & $(-132,4458)$ & $0,0616^{* * *}$ & $0,0611^{* * *}$ \\
& $0,0462^{* * *}$ & $(5,7885)$ & $(5,7486)$ \\
\hline Observations & $(16,9774)$ & 730 & 730 \\
$\mathrm{R}^{2}$ & 730 & 0,9685 & 0,3674 \\
\hline Likelihood test $(\chi 2)$ & $2344,8760.000$ & & \\
Hausman test $(\chi 2)$ & $71,0510.0000$. & & \\
\hline
\end{tabular}

Notes: LP1 is the natural logarithm base on labor productivity which defined by revenue divided by company's employees. LW is the natural logarithm based on wage; LE is the natural logarithm based on the number of employees; A is the age of the company.

In Table 2, the results of regression which labor productivity using total revenue divided by the number of employees in the same period. The regression results in Table 2 were calculated by 3 methods: Pooled, FEM and REM. The Likelihood and Hausman test results confirmed the 
results of FEM model is the most qualitative that present the impact of some factors on labor productivity in the companies. The study results showed that wage has a positive impact on labor productivity with the significance of $1 \%$, meanwhile, if the wage increases $1 \%$, the labor productivity will increase $0.0764 \%$. Next, the amount of employees has a negative impact on labor productivity with $1 \%$ of significance, particularly if the number of employees increases $1 \%$, labor productivity decreases $0.7292 \%$. Finally, the age of companies has a positive impact on labor productivity at the significance of $1 \%$, in that if the age of company increase 1 year, the labor productivity also increased $0.0616 \%$.

Results have shown that companies should focus on increase the wage, cut back the number of employees. In addition, study results also imply if the business has greater seniority in the market, labor productivity is also improved.

Tab. 3 - Results using data regression variables LP2. Source: Calculated from the research data

\begin{tabular}{|l|l|l|l|}
\hline Dependent variable: $L P 2$ & FEM & REM \\
\hline Variable & PM & $668,788^{* * *}$ & $693,1181^{* * *}$ \\
\hline C & $722,2389^{* * *}$ & $(9,4431)$ & $(9,8543)$ \\
\hline LW & $(89,6618)$ & $0,1918^{* * *}$ & $0,3071^{* * *}$ \\
& $0,4443^{* * *}$ & $(3,0345)$ & $(6,3991)$ \\
\hline LE & $(151,0421)$ & $-0,3739^{* * *}$ & $-0,3761^{* * *}$ \\
& $-0,3693^{* * *}$ & $(-2,6223)$ & $(-6,5257)$ \\
\hline $\mathrm{A}$ & $(-142,8393)$ & $0.3241^{* * *}$ & $0,3071^{* * *}$ \\
& $0,3527^{* * *}$ & $(9,1846)$ & $(6,3991)$ \\
\hline Observations & $(8,0280)$ & 730 & 730 \\
$\mathrm{R}^{2}$ & 730 & 0,8465 & 0,1956 \\
\hline Likelihood test $(\chi 2)$ & $1159,8350,000$. & & \\
Hausman test $(\chi 2)$ & $10,06740,0180$. & & \\
\hline
\end{tabular}

Notes: LP2 is the natural logarithm base on labor productivity which defined by profit after tax divided by company's employees. LW is the natural logarithm based on wage; LE is the natural logarithm based on the number of employees; A is the age of the company.

In the following, the results in Table 3 presents the factors affecting labor productivity. Particularly, labor productivity was based on the total profit after the tax divided by the employees in the same period. Likelihood and Hausman test results continue to assert the estimation of FEM method is the most suited to the research data. In particular, the research results continue to confirm the wage increase has the effect of promoting labor productivity. Specifically, if the wage increases $1 \%$, the labor productivity will increase by $0.4105 \%$ at $1 \%$ statistical significance. Conversely, if the number of employees (E) increase $1 \%$, the labor productivity will be fell $0.3669 \%$ at $1 \%$ statistical significance. Finally, when the age of company increases 1 year, the labor productivity will increase by $0.3241 \%$ at the significance of $1 \%$.

Results also showed that $\mathrm{R} 2=22.53 \%$ meaning that the independent variables included in the regression model on the likely explanation approximated $22.53 \%$ of the variation in the average of the dependent variable. Once again, the results present that labor productivity increase if managers will increase the wage as well as reduced the number of employees. Besides, when the age of firms increase that lead to labor productivity also increases. 


\section{CONCLUSIONS AND RECOMMENDATIONS}

In this study, the data collected from 240 companies (with 730 observations) listed on the Stock Exchange in Vietnam from 2011 to 2013 is applied to clarify the relationship between labor productivity and a number of factors such as wages, a number of employees and the age of the company.

Research's results have shown a positive relationship between wages and labor productivity in the business. In general, labor productivity increases help firms offset the "shock wage increase" when cost increases, so do not occur layoffs or declining profits from the rising cost of wages bring. From there to increase employee productivity, enterprises require the continuous policy of wage increases, increase the form of bonuses. Wages are one of the most important economic instruments in the management of labor, this is a useful tool to help promote work motivation of workers since labor productivity will increase.

In addition, the amount of labor negatived relationship with labor productivity of firms during the study. In essence, Vietnam enterprises have not paid attention to labor. The cause could be Vietnam has cheap manpower so enterprises can not attach importance to the effective use of labor. Moreover, the trend of firms that recruit the labor shortage without considering the restructuring work should result in wasted labor. So rising labor costs lead to reduced productivity. Currently, the size of the enterprise labor Vietnam increased rapidly, but in fact, the use is now only about $40 \%$ of the capacity of human resources that they own. Therefore, this is an illustration of warning to firms if continue hired labor without regard to the quality will lead to reduced labor productivity or worse can now bear the losses because the cost labor increased but not associated with increased output respectively.

Finally, the results of the study confirmed the age of firms related to labor productivity. Thus, the results showed that firms seem increasingly senior business on the market, the bigger the high labor productivity. The results imply that the senior enterprises often apply a lot of management solutions, methods of production and new technologies from which to promote increased labor productivity.

\section{REFERENCES:}

1. Basker E. (2012), Rasing the barcode scanner: Technology and productivity in the retail sector, NBER Working Paper No. 17825. http://www.nber.org/papers/w17825

2. Drewin, F, J., (1982), Construction productivity: Measurement and Improvement though work study, Elsevier Science Publishing Co., Netherlands

3. Ingene, A. (1982), "Labor productivity in retail", Journal of Marketing, 46(4), 75- 99. https://www.jstor.org/stable/1251364

4. Borcherding, D., Liou, S. (1986), Work sampling can predict unit rate productivity, Journal of Construction Engineering and Management, 112(1), 90-103. http://dx.doi.org/10.1061/(ASCE)0733-9364(1986)112:1(90)

5. Jarkas, M. (2010), Buildability factors influencing formwork labour productivity of isolated foundations, Journal of Engineering, Design and Technology, 8 (3), 274-295. http://dx.doi.org/10.1108/17260531011086162

6. Isinika A. C. (1995), Assessing the effect of agricultural research expenditure on agricultural productivity in Tanzania, the University of Kentucky, USA. http://elibrary.ru/item.asp?id=5397862 
7. Han F., Leong D. (1996), Productivity \& Service Quality, Prentice Hall, Simon \& Schuster (Asia) Pte Ltd, Singapore. ISBN: 98130766079789813076600

8. Lee, X., Yuen, F. (2015), Will minimum wage translate into higher productivity? A case analysis of manufacturing firms in Malaysia, International Journal of Education and Research, 3(4), 453-464.

www.ijern.com/journal/2015/April-2015/38.pdf

9. N.Gregory Mankiw (2010), Macroeconomics (7 $7^{\text {th }}$ Edition), Worth Publishers, USA. ISBN:1285165918

10. Rama, M. (2001), The Consequences of Doubling the Minimum Wage: The Case of Indonesia, Industrial and Labor Relations Review, 54 (4), 864-881. DOI: $10.2307 / 2696117$

11. Mayneris, F., Poncet S., Zhang. T, (2014), The cleansingeffect of minimum wage: Minimum wage rules, firmdynamics and aggregate productivity in China, CEPII Working Paper.

https://www.wto.org/english/res_e/reser_e/gtdw_e/wkshop14_e/florian_mayneris_e.p df

12. Riley R. \& Bondibene C. R. (2013), The impact of the national minimum wage on firm behaviour during recession, Report to the Low Pay Commission (Working paper), National Institute of Economic and Social Research, London, UK. http://www.niesr.ac.uk/publications/impact-national-minimum-wage-firm-behaviourduring-recession\#.WNh6ox-g_IV

13. Park, A. (2008), Evaluating Labor Productiviy in Food Retailing, Agricultural and Resource Economics Rewiew, 288-300. https://doi.org/10.1017/S1068280500003063

14. Siebert S., Zubanov N., Chevalier A., Viitanen T. (2006), Labour turnover and labour productivity in a retail organization, IZA Discussion Paper, No. 2322. http://ftp.iza.org/dp2322.pdf

15. Singh, S. (2014), Production and Operations Management, Vikas Publishing House, India. http:/www.kopykitab.com/ebooks/2014/11/3797/sample/sample_3797.pdf

16. Sziraczki, G., (2015), Why is labour productivity important in economic integration?, ILO working papers, Switzerland.

http://www.ilo.org/hanoi/Informationresources/Publicinformation/newsitems/WCMS 340867/lang--en/index.htm

17. Thurik, R., Kleijweg, M. (1986), Procyclical retail labour productivity, Bulletin of Economic Research, 38 (2), 169-175. http://DOI: 10.1111/j.1467-8586.1986.tb00212.x

18. Wimmer, B. (2000), "The Minimum Wage and Productivity Differentials", Journal of Labor Research, 21(4), 649-668. http://DOI: 10.1007/s12122-000-1038-8 


\section{Contact informations}

\section{Le Thanh Tung, PhD.}

Faculty of Business Administration, Ton Duc Thang University

Address: No. 19, Nguyen Huu Tho street, Tan Phong ward, district 7, Ho Chi Minh City, Vietnam. Email: lethanhtung@tdt.edu.vn

\section{Lam Thanh Hieu}

Faculty of Business Administration, Ton Duc Thang University

Address: No. 19, Nguyen Huu Tho street, Tan Phong ward, district 7, Ho Chi Minh City, Vietnam. Email: 71306106@student.tdt.edu.vn

\section{Hoang Thi Trang}

Faculty of Business Administration, Ton Duc Thang University

Address: No. 19, Nguyen Huu Tho street, Tan Phong ward, district 7, Ho Chi Minh City, Vietnam. Email: 71306393@ student.tdt.edu.vn 